\title{
Mutations and Modifier Genes: Everything that Governs Congenital Long QT Syndrome
}

\author{
Amritphale $\mathrm{N}^{1 *}$, Khilji $\mathbf{0}^{1}$, Varghese $\mathrm{B}^{2}$, Dubey $\mathrm{D}^{3}$ and Amritphale $\mathrm{A}^{2}$ \\ ${ }^{1}$ Texas Tech University Health Sciences Center, EIPaso, USA \\ ${ }^{2}$ Oklahoma University Health Sciences Center, USA \\ ${ }^{3}$ Mayo Clinic, Rochester, USA \\ Submission: October 29, 2018; Published: December 05, 2018 \\ *Corresponding author: Amritphale N, Texas Tech University Health Sciences Center, ElPaso, Texas, USA
}

\begin{abstract}
Congenital long QT syndrome (LQTS) is a genetically heterogeneous disorder predisposing to ventricular arrhythmias as well as sudden cardiac death. It has been clearly identified that along with genetically determined mutations, there is a presence or absence of associated genes that can modify the outcome or presentation of the cardiac illness. In this article, we will outline the current knowledge about the genetics of LQTS, its different modes of transmission, role of modifier genes and their combined association with severity.
\end{abstract}

Keywords: Long QT syndrome; Modifier genes; Nitric oxide synthase; KCNQ1; K897T; Arrhythmia

Abbreviations: LQTS: Long QT Syndrome; RW: Romano-Ward

\section{Introduction}

Long-QT syndrome (LQTS) is a life-threatening disorder of myocardial repolarization that can lead to symptomatic ventricular arrhythmias and an increased risk of sudden cardiac death. LQTS is typically characterized by a prolongation of the QT interval on the ECG and by the occurrence of syncope, seizures or cardiac arrest which may be precipitated by stress. Patients without symptoms typically come to medical attention because they have an affected family member, or a prolonged QTc (QT interval corrected for heart rate) is identified on an ECG obtained for some other reason.

Long-QT syndrome can be subclassified into congenital and acquired forms. Since 1975, two hereditary variants, the RomanoWard (RW) syndrome and the Jervell and Lange-Nielsen (JLN) syndrome have been included under the comprehensive name of LQTS. While the Romano Ward syndrome is inherited autosomal dominant is purely cardiac in its presentation, on the other hand the Jervell-Lange Nielsen syndrome is an autosomal recessive inheritance but projects a more malignant course involving sensorineural deafness along with the cardiac involvement.

Apart from Jervell-Lange-Nielsen syndrome and RomanoWard syndrome, others including Andersen-Tawil syndrome, Timothy syndrome and some instances of sudden infant death syndrome, have been linked with the LQTS. There may be certain medications such as antidepressants or antihistamines which may unmask previously unsuspected congenital concealed mutations even in the absence of an underlying mutation. These will be defining the acquired variety of Long QT syndromes.
LQTS is the one of the most common cardiac illnesses in which molecular biology and genetics have made the greatest progress and is clearly the best example of genotype-phenotype correlation [1]. These include mutations in genes expressing cardiac ion channels, membrane proteins as well as other trafficking proteins which may harbor the genes defining the long QT syndromes on the molecular levels. Thirteen genetic forms of LQTS have been described, starting from LQT1-LQT13, based on the order of discovery. Approximately 50 genetic mutations have been identified in 4 critical cardiac ion channels causing inherited LQTS syndromes. Apart from the occurrence of mutations in the cardiac ion channels, there is also a different set of genes whose presence or absence might define the expression as well as guide the outcome of the cardiac events.

\section{Discussion}

A total of thirteen different genes have been identified so far to be linked with LQTS. In patients with a genetic diagnosis, approximately 45\% have LQT1, 34\% have LQT2, and 10\% have LQT3. It is clear that LQT3 is one of the least common mutations, but at the same time it is also associated with the most number of fatal events. Studies have shown that $20 \%$ of cardiac events in patients with LQT3 were likely to be fatal vs only $4 \%$ of events in LQT1 and LQT2 [2]. The mechanism of inheritance however is a completely different theme. It has been seen that the mutations may exhibit incomplete penetrance or variable expressivity. There may also be environmental or developmental factors governing the same. 
Clinical heterogeneity among patients with long-QT syndrome (LQTS) having a common mutation is usually attributed to variable penetrance [3]. Modifier genes are different from the disease-causing mutation. Single nucleotide polymorphisms may modulate the clinical severity of the primary mutation as well as alter the arrhythmia susceptibility. Crotti et all established the phenomenon in a 44-year-old white woman, later diagnosed with LQT2 after the identification of a missense KCNH2 mutation (A1116V) altering a conserved residue in the distal carboxylterminus of the encoded HERG protein. It was seen that the same lady also carried K987T on a non-mutant allele. Relatives who carried A1116V alone without K897T were largely asymptomatic. Thus, the occurence of KCNH2-K897T together was predicted to exaggerate the response caused by the A1116V mutation and also predict the severity of the cardiac involvement [4].

It is important to know that potassium channels are one of the important ionic channels affecting cardiac function. On the molecular level, there are 2 major inward rectifying potassium current channels: a slowly activating channel $\left(\mathrm{I}_{\mathrm{KS}}\right)$ and a rapidly activating channel $\left(\mathrm{I}_{\mathrm{Kr}}\right)$. Each of these channels is composed of its own $\alpha$ and $\beta$ subunits. Four $\alpha$ subunits assemble with minK $\beta$ subunits to create the $\mathrm{I}_{\mathrm{Ks}}$ channel while the same 4 alpha subunits join with MiRP1 $\beta$-subunits to create the $\mathrm{I}_{\mathrm{Kr}}$ channel.

One of the important mutations being studied in great detail is the combination of KCNQ1/A341V. The KCNQ1 gene (previously published as KVLQT1), encodes the $\alpha$ subunit of the $\mathrm{I}_{\mathrm{Ks}}$ channel. These mutations were definitely associated with LQT1 genotype. Crotti et all conducted on of the largest study to find out whether the presence of this gene in a common ethnic background of South Africa does anyway influence the outcome of cardiac arrhythmias. It has been proven with clear evidence that the cardiac consequences were similar in populations all over the world or South Africa, thus proving that ethnicity does not have a great effect as long as the modifier genes are present in combination. Thus, it was identified that the hot spot KCNQ1A341V predicts high clinical severity independently of the ethnic origin of the families [5].

The most powerful resource for studying modifier genes is represented by founder populations, in which a disease allele segregates in families descending from a common ancestor. It was determined that clinical severity of LQTS observed in the SA-A341V population is significantly greater than the other phenotypic presentations of long QT syndrome [6]. This study established a more severe arrhythmogenic outcome after $10 \mathrm{yrs}$ of age for individuals with $\mathrm{A} 341 \mathrm{~V}$ mutation while it was not related to some unknown factor associated with their permanence in South Africa $[7,8]$. Thus, ethnicity may not be playing a major role everywhere and our research should more focus on the presence of these modifier genes.

Recent evidence indicates that common variants in NOS1AP are associated with the prolongation of the QT-interval duration in the general population. In an unusually large South African LQT1 founder population, they found a new class of modifier genes in the form of 2 common variants in NOS1AP namely the rs4657139 and rs16847548. They were known to encode a nitric oxide synthase adaptor protein, which were significantly associated with occurrence of symptoms and along with clinical severity and prolongation of QT interval. They have been associated with the probability of having QTc duration in the top $40 \%$ of all QTc values among mutation carriers. At the same time, the presence of this gene portends a bad prognosis in the form of sudden death risk in individuals $[9,10]$.

\section{Conclusion}

Dissecting how genetic variation alters the electrical substrate has been the target of many investigations and an area of intense current research. Identifying these modifier factors illustrates the limitations of the cellular models currently used in the assessment of a functional defect. These models allow the biophysical investigation of putative mutations in single ion channels, potentially with the co expression of specific variant.

Moretti et al reprogrammed fibroblasts derived from members of a family with autosomal-dominant long-QT syndrome type 1 and used these induced pluripotent stem cells to generate patientspecific cardiomyocytes [11-13]. It showed clearly that patients with long-QT syndrome type 1 exhibited certain characteristics such as prolongation of the action potential, altered $\mathrm{I}_{\mathrm{Ks}}$ properties, and an abnormal response to catecholamine stimulation, with a protective effect of beta-blockade, thus establishing that induced pluripotent stem-cell models can recapitulate concepts of genetically mediated cardiac illnesses. Thus, the patientderived cells recapitulated the electrophysiological features of the disorder. It is definitely a domain which needs more unlocking and can essentially play a crucial role in determining our decisions based on the underlying genetics.

While deciding on the need for therapy, the dilemma of deciding whether the patient population needs an implantable defibrillator, besides receiving beta-blockers, should be based on risk stratification schemes based on clearly defined epidemiological studies. We have always known that QT interval, sex, and genetic locus are the most important determinants of risk in LQT1, LQT2, and LQT3 [14]. Now, we may need to explore the role of modifier genes in congenital cardiac syndromes, which could help to refine risk stratification.

\section{Conflict of Interest}

None of the authors have any conflict of interest.

\section{References}

1. Qureshi SF, Ali A, Venkateshwari A, Rao H, Jayakrishnan MP, et al. (2015) Genotype-phenotype correlation in long QT syndrome families. Indian Pacing Electrophysiol J 15(6): 269-285.

2. Zareba W, Moss AJ, Schwartz PJ, Vincent GM, Robinson JL, et al. (1998) Influence of the genotype on the clinical course of the long-QT syndrome. International Long-QT Syndrome Registry Research Group. N Engl J Med 339(14): 960-965. 
3. Baruteau AE, Kyndt F, Behr ER, Vink AS, Lachaud M, et al. (2018) SCN5A mutations in 442 neonates and children: genotypephenotype correlation and identification of higher-risk subgroups. Eur Heart J 39(31): 2879-2887.

4. Crotti L, Lundquist AL, Insolia R, Pedrazzini M, Ferrandi C, et al. (2005) KCNH2-K897T is a genetic modifier of latent congenital long-QT syndrome. Circulation 112(9): 1251-1258.

5. Crotti L, Spazzolini C, Schwartz PJ, Shimizu W, Denjoy I, et al. (2007) The common long-QT syndrome mutation KCNQ1/A341V causes unusually severe clinical manifestations in patients with different ethnic backgrounds: toward a mutation-specific risk stratification. Circulation 116(21): 2366-2375.

6. Brink PA, Schwartz PJ (2009) Of founder populations, long QT syndrome, and destiny. Heart Rhythm 6(11 Suppl): S25-S33.

7. Brink PA, Crotti L, Corfield V, Goosen A, Durrheim G, et al. (2005) Phenotypic variability and unusual clinical severity of congenital longQT syndrome in a founder population. Circulation 112(17): 26022610 .

8. Schwartz PJ (2011) Sudden cardiac death, founder populations, and mushrooms: what is the link with gold mines and modifier genes? Heart Rhythm 8(4): 548-550.

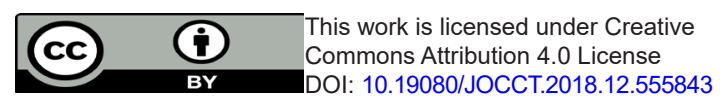

9. Crotti L, Monti MC, Insolia R, Peljto A, Goosen A, et al. (2009) NOS1AP is a genetic modifier of the long-QT syndrome. Circulation $120(17)$ : $1657-1663$

10. Tomás M, Napolitano C, De Giuli L, Bloise R, Subirana I, et al. (2010) Polymorphisms in the NOS1AP gene modulate QT interval duration and risk of arrhythmias in the long QT syndrome. J Am Coll Cardiol 55(24): 2745-2752.

11. Moretti A, Bellin M, Welling A, Jung CB, Lam JT, et al. (2010) Patientspecific induced pluripotent stem-cell models for long-QT syndrome. N Engl J Med 363: 1397-1409.

12. Itzhaki I, Maizels L, Huber I, Zwi-Dantsis L, Caspi O, et al. (2011) Modelling the long QT syndrome with induced pluripotent stem cells. Nature 471(7337): 225-229.

13. Malan D, Friedrichs S, Fleischmann BK, Sasse P (2011) Cardiomyocytes obtained from induced pluripotent stem cells with long-QT syndrome 3 recapitulate typical disease-specific features in vitro. Circ Res 109(8): 841-847.

14. Priori SG, Schwartz PJ, Napolitano C, Bloise R, Ronchetti E, et al. (2003) Risk stratification in the long-QT syndrome. N Engl J Med 348: 18661874.

\begin{tabular}{l} 
Your next submission with Juniper Publishers \\
will reach you the below assets \\
- Quality Editorial service \\
- Swift Peer Review \\
- Reprints availability \\
- E-prints Service \\
- Manuscript Podcast for convenient understanding \\
- Global attainment for your research \\
- Manuscript accessibility in different formats \\
( Pdf, E-pub, Full Text, Audio) \\
- Unceasing customer service \\
Track the below URL for one-step submission \\
https://juniperpublishers.com/online-submission.php \\
\hline
\end{tabular}

